education has been neglected until recently. Parry ${ }^{14}$ suggested that catatonia may be a modern complication of typhoid fever in patients who have been effectively treated. Similar patients in an earlier era might well have died.

Ours was a selected group of patients referred because of the severe and unusual nature of their illness. Nevertheless, typhoid catatonia cannot be considered a rarity, and its recognition by physicians and psychiatrists is clearly important for effective treatment.

\author{
References \\ ${ }^{1}$ Schwab, J J, and Barow, M V, American fournal of Psychiatry, 1974, 120, \\ 1196. \\ 2 Zlotlow, M, and Kleiner, S, Psychiatry, 1965, 39, 467.
}

${ }^{3}$ Hockaday, T D R, Keynes, W M, and McKenzie, J K, British Medical Fournal, 1966, 1, 85.

${ }^{4}$ Koehler, K, and Jakumeit, U, British fournal of Psychiatry, 1976, 129, 29.

${ }^{5}$ Good, M I, American fournal of Psychiatry, 1976, 133, 1454.

${ }^{6}$ Pathania, N S, and Sachar, R S, American fournal of Tropical Medicine and Hygiene, 1965, 14, 419.

${ }^{7}$ Gadeholt, H, and Madsen, S T, Acta Medica Scandinavica, 1963, 174, 753.

${ }^{8}$ Stuart, B M, and Pullen, R L, Archives of Internal Medicine, 1946, 78, 629.

${ }^{9}$ Osuntokun, B O, et al, Archives of Neurology, 1972, 27, 7.

10 Bleuler, E, Dementia Praecox or the Group of Schizophrenias, trans Joseph Zinkin, p 248. New York, International Universities Press, 1950.

${ }_{11}$ Muhangi, J R, African fournal of Medical Science, 1972, 3, 319.

12 Schneider, K, Clinical Psychopathology, trans M W Hamilton. New York, Grune and Stratton, 1959.

${ }^{13}$ Roth, M, and Rosie, J M, fournal of Mental Science, 1953, 99, 103.

14 Parry, E H O, personal communication.

(Accepted 30 March 1977)

\title{
Bleeding in renal failure: Is von Willebrand factor implicated?
}

\author{
G REMUZZI，M LIVIO， M C RONCAGLIONI， G MECCA，M B DONATI， G DE GAETANO
}

\section{Summary}

Normal or increased concentrations of factor VIII procoagulant activity (VIIIC), factor VIII-related antigen (VIIIRA), and factor VIII-von Willebrand activity (VIIIVWF) were found in the predialysis plasma of 10 out of 11 patients with chronic renal failure (CRF). All patients had a bleeding time longer than 15 minutes and platelet retention to glass beads lower than $40 \%$. The only patient who had reduced concentrations of all three factor VIII complex components was subsequently shown to have von Willebrand's disease. In four patients with CRF, very low platelet retention, and slightly prolonged bleeding time none of the three factor VIII complex components were selectively modified in predialysis samples.

These findings suggest that the bleeding tendency common in CRF is not necessarily linked to defective plasma factor VIII-related activities.

\section{Introduction}

Uraemia is often complicated by a haemorrhagic diathesis. Extensive investigations have failed to identify with any certainty the cause of bleeding in chronic renal failure (CRF).$^{1-3}$ Different defects of platelet function described in patients with CRF have been attributed to one or more of the metabolites abnor-

Nephrology and Dialysis Division, Ospedali Riuniti di Bergamo, Bergamo

GUISEPPE REMUZZI, MD, assistant in nephrology

GIULIANO MECCA, $M D$, chief of division

Instituto di Ricerche Farmacologiche "Mario Negri," 62-20157 Milan MANUELA LIVIO, BIOLSCID, postgraduate fellow

MARIA CARLA RONCAGLIONI, medical student

MARIA BENEDETTA DONATI, MD, PHD, laboratory chief

GIOVANNI DE GAETANO, MD, PHD, laboratory chief mally accumulating in uraemic plasma. ${ }^{3-5}$ Nevertheless, platelet function values are often unchanged after dialysis and the usually prolonged bleeding time is only occasionally shortened, though results have varied. ${ }^{6-8}$

Recently Kazatchkine et $a l^{7}$ found a reduced amount of von Willebrand factor (ristocetin cofactor; VIIIVWF) in the plasma of patients with CRF and suggested that this was a possible cause of bleeding in this condition. The finding is of interest in view of the general opinion that VIIIVWF is necessary for controlling skin bleeding time and for normal platelet retention on glass beads. ${ }^{9-11}$ Kazatchkine $e t$ al did not find that VIIIVWF concentrations were increased by dialysis. ${ }^{\text {? }}$

As part of a broader study on the causes of bleeding in CRF, ${ }^{8}$ we investigated VIIIVWF and the other factor VIII complex components (factor VIII procoagulant activity (VIIIC) and factor VIII-related antigen (VIIIRA)) in a selected group of patients on long-term haemodialysis who had very prolonged bleeding times and very low platelet retention.

\section{Patients and methods}

Eleven patients with CRF (due to chronic glomerulonephritis in 10 and chronic pyelonephritis in one) who had been undergoing maintenance haemodialysis for one month to eight years were studied immediately before a routine dialysis-that is, 68 hours after the end of the last dialysis. These patients had bleeding times longer than 15 minutes and platelet retention on glass lower than $40 \%$ on several occasions before this study. The individual values obtained when blood was collected for factor VII measurements are shown in the table. Platelet counts were repeatedly found to be normal in each of these patients (range $170-300 \times 10^{9} / 1$ ).

Blood samples before dialysis were also obtained from four nonthrombocytopenic patients with CRF (chronic glomerulonephritis in three and chronic pyelonephritis in one) who had platelet retention lower than $40 \%$ but only slightly prolonged bleeding times ( 3 minutes 30 seconds to 5 minutes 45 seconds). The 15 patients with CRF were all receiving $12 \mathrm{~m}^{2}$ hours per week of haemodialysis in thrice weekly sessions. The dialyser used was the Coil Kidney with cuprophane membrane. Blood flow was more than $300 \mathrm{ml} / \mathrm{min}$ and water flow was $500 \mathrm{ml} / \mathrm{min}$.

Ten normal subjects (four women and six men aged 20-46 years) were also studied. Their bleeding times ranged from 2 minutes 30 seconds to 3 minutes 30 seconds, and they retained $56 \%$ to $98 \%$ of platelets on glass beads. The bleeding times in 30 normal subjects 
ranged from 1 minute 30 seconds to 4 minutes, and platelet retention from $63 \%$ to $98 \%$.

None of the patients or controls had received any blood transfusions or any drug known to affect platelet function for at least five months before investigation.

Bleeding time was determined in duplicate by an automatic templatelike device. ${ }^{12}$ Platelet retention on glass beads was measured in native blood by a modification of Hellem's method, ${ }^{13}$ using commercial glass bead columns (Adeplat $S$ ) and a constant-rate $(1 \mathrm{ml} / 15 \mathrm{~s})$ pump (Adeplat "S" Pump System, Mascia Brunelli, Milan, Italy). ${ }^{14}$

Blood was collected in $0 \cdot 126-\mathrm{M}$ trisodium citrate solution (nine parts of blood to one part anticoagulant solution). Platelet-poor plasma, obtained as described, ${ }^{14}$ was rapidly frozen at $-20^{\circ} \mathrm{C}$ in small aliquots and thawed at $37^{\circ} \mathrm{C}$ only once, just before testing. VIIIC was measured by a one-stage assay using a kit from Immuno Diagnostica, Pisa, Italy. VIIIRA was assayed by unidimensional immunoelectrophoresis in antibody-containing gel, ${ }^{15}$ as described by the Italian Working Group. ${ }^{16}$ Rabbit antiserum was obtained from Behringwerke Hoechst Italia, Milano, Italy. The plasma cofactor of ristocetin-induced platelet aggregation (VIIIVWF) was measured by the quantitative assay of Weiss et al, ${ }^{17}$ using formalin-fixed platelets as described by Macfarlane et al. ${ }^{18}$ The sensitivity of the aggregometer (Elvi 840, Elvi Logos, Milano, Italy) was increased by using a $1 / 1$ dilution of platelet suspension with saline to set the $100 \%$ light transmission. ${ }^{19}$ Aggregation by ristocetin $(1 \mathrm{mg} / \mathrm{ml}$ final concentration, Mascia Brunelli, Milan, Italy) was estimated by measuring both the slope of the steepest part of the tracing and its maximum amplitude. Both values were plotted against the plasma dilution on a $\log / \log$ scale and expressed as percentages of the normal standard (three pools of plasma from three to 10 normal individuals). The samples of plasma to be tested were appropriately diluted in albumin containing saline (usually between $1 / 10$ and $1 / 160$ final dilution) to bring their aggregation values into the linear portion of the reference curve. ${ }^{20}$ Three different platelet concentrates were used in this study and each test plasma was assayed on at least two of them.

\section{Results}

VIIIC, VIIIRA, and VIIIVWF concentrations in patients with CRF undergoing haemodialysis are shown in the table and figure. In all the patients with bleeding times longer than 15 minutes VIIIC was within the normal range, whereas VIIIRA and VIIIVWF were increased. The patient who showed the lowest values of the group for all three factor VIII components (case 11) was a 55-year-old man with a lifelong history of bleeding diathesis before the onset of glomerulonephritis. von Willebrand's disease had not been diagnosed when he was referred to the nephrology department. After the completion of our investigation, studies on the patient's pedigree and on the evolution of plasma factor VIII components on cryoprecipitate transfusion confirmed that he had von Willebrand's disease.

In the four patients with slightly prolonged bleeding times the data obtained showed wide individual variability, but no sharp discrepancy could be observed between the values of the three factor VIII components.

\section{Discussion}

In this selected group of patients undergoing haemodialysis who had very prolonged bleeding times (over 15 minutes) and very low platelet retention on glass beads (less than $40 \%$ ) the levels of factor VIII complex components were either normal or increased. This finding agrees with those of several other workers, ${ }^{2}>21$ but is at variance with the recent finding of Kazatchkine et al, that VIIIVWF levels were selectively reduced in CRF. ${ }^{7}$ From our results it seems that abnormal bleeding time and platelet retention in CRF may be associated with normal or even increased levels of VIIIVWF.

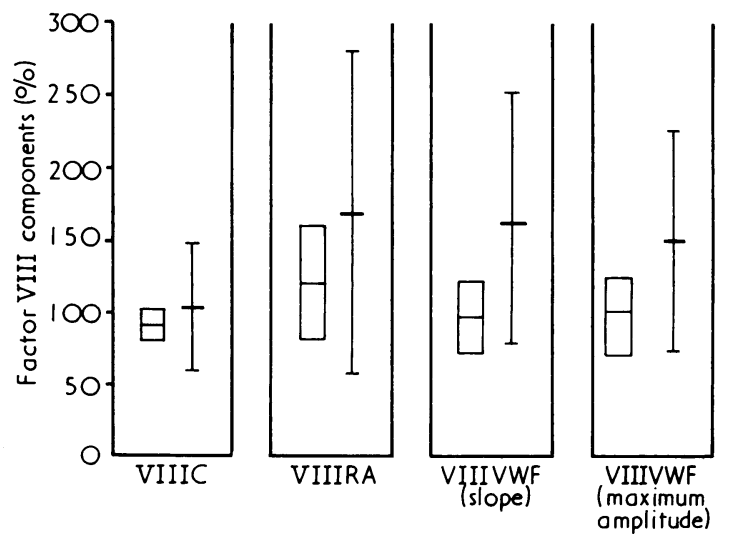

Mean VIIIC, VIIIRA, and VIIIVWF levels $(t S D)$ in 11 patients with CRF and bleeding times longer than 15 minutes. Values obtained in 10 controls are indicated by boxes on left.

The lack of a close link between these values in our patients is further supported by the observation that two patients (cases 13 and 15) had low VIIIVWF levels but only moderately prolonged bleeding times. The dissociation between bleeding times and levels of VHIIVWF is in line with the observations of Ratnoff and Bennett ${ }^{22}$ and Mannucci et $a l^{23}$ that the bleeding time in patients with von Willebrand's disease remained abnormal after infusion of cryoprecipitate or of a vasopressin analogue, despite a considerable increase in plasma factor VIII components.

The discrepancy between our data and those of Kazatchkine et $a l^{7}$ may be due to several factors. The most important may be the fact that we selected uraemic patients with pronounced abnormalities of both bleeding time and platelet retention, whereas Kazatchkine et al, who did not report the values of

Bleeding time, platelet retention, and factor VIII components in 15 patients with chronic renal failure on maintenance haemodialysis. Values for VIIIVWF were calculated from both the slope and the maximum amplitude of ristocetin-induced platelet aggregation tracings

\begin{tabular}{|c|c|c|c|c|c|c|c|c|}
\hline \multirow{2}{*}{$\begin{array}{l}\text { Case } \\
\text { No }\end{array}$} & \multirow{2}{*}{ Age and sex } & \multirow{2}{*}{$\begin{array}{c}\text { Dialysis } \\
\text { treatment } \\
\text { (months) }\end{array}$} & \multirow{2}{*}{$\begin{array}{l}\text { Bleeding } \\
\text { time } \\
\text { (min) }\end{array}$} & \multirow{2}{*}{$\begin{array}{c}\text { Platelet } \\
\text { retention } \\
(\%)\end{array}$} & \multirow{2}{*}{$\underset{(\%)}{\operatorname{VIIIC}}$} & \multirow{2}{*}{$\begin{array}{l}\text { VIIIRA } \\
(\%)\end{array}$} & \multicolumn{2}{|c|}{ VIIIVWF $(\%)$} \\
\hline & & & & & & & Slope & $\begin{array}{l}\text { Maximum } \\
\text { amplitude }\end{array}$ \\
\hline \multicolumn{9}{|c|}{ Patients with greatly prolonged bleeding times } \\
\hline $\begin{array}{r}1 \\
2 \\
3 \\
4 \\
5 \\
6 \\
7 \\
8 \\
9 \\
10 \\
11\end{array}$ & $\begin{array}{l}30 \mathrm{~F} \\
41 \mathrm{M} \\
26 \mathrm{M} \\
30 \mathrm{M} \\
35 \mathrm{M} \\
26 \mathrm{M} \\
24 \mathrm{~F} \\
33 \mathrm{M} \\
50 \mathrm{~F} \\
45 \mathrm{M} \\
55 \mathrm{M}\end{array}$ & $\begin{array}{r}69 \\
33 \\
39 \\
27 \\
96 \\
5 \\
1 \\
1 \\
42 \\
37 \\
37\end{array}$ & $\begin{array}{r}>15 \\
>15 \\
>15 \\
>15 \\
>15 \\
>15 \\
>15 \\
>15 \\
>15 \\
>15 \\
>15\end{array}$ & $\begin{array}{l}20 \\
16 \\
29 \\
31 \\
28 \\
27 \\
20 \\
39 \\
30 \\
27 \\
11\end{array}$ & $\begin{array}{r}110 \\
140 \\
100 \\
90 \\
50 \\
154 \\
80 \\
132 \\
176 \\
83 \\
30\end{array}$ & $\begin{array}{r}312 \\
264 \\
106 \\
78 \\
150 \\
74 \\
132 \\
188 \\
400 \\
106 \\
48\end{array}$ & $\begin{array}{r}181 \\
221 \\
108 \\
138 \\
112 \\
126 \\
133 \\
168 \\
336 \\
274 \\
16\end{array}$ & $\begin{array}{r}128 \\
224 \\
108 \\
118 \\
108 \\
126 \\
132 \\
160 \\
299 \\
235 \\
17\end{array}$ \\
\hline \multicolumn{9}{|c|}{ Patients with slightly prolonged bleeding times } \\
\hline $\begin{array}{l}12 \\
13 \\
14 \\
15\end{array}$ & $\begin{array}{l}41 \mathrm{~F} \\
25 \mathrm{M} \\
38 \mathrm{M} \\
30 \mathrm{M}\end{array}$ & $\begin{array}{r}67 \\
69 \\
37 \\
5\end{array}$ & $\begin{array}{l}5 \min 30 \mathrm{~s} \\
4 \min 45 \mathrm{~s} \\
3 \min 30 \mathrm{~s} \\
5 \min 45 \mathrm{~s}\end{array}$ & $\begin{array}{l}10 \\
19 \\
30 \\
10\end{array}$ & $\begin{array}{r}300 \\
50 \\
90 \\
50\end{array}$ & $\begin{array}{r}312 \\
56 \\
330 \\
80\end{array}$ & $\begin{array}{r}592 \\
23 \\
137 \\
56\end{array}$ & $\begin{array}{r}448 \\
20 \\
134 \\
61\end{array}$ \\
\hline
\end{tabular}


either test, may not have selected their patients on the basis of these values. Therefore, the patients we studied might not be comparable with those examined by these authors. In addition, we measured VIIIVWF using formalin-treated and not freshly prepared washed platelets, although in the few cases in which VIIIVWF was also assayed on platelets obtained as described by Kazatchkine et al the values obtained did not differ from those reported in the table. Our data do not rule out the possibility that a low plasma VIIIVWF level, if present, might contribute to the bleeding tendency of some patients with CRF. They do, however, also imply that a selective defect of VIIIVWF is probably an uncommon finding in patients with CRF and abnormal bleeding time and platelet retention.

The practical implication of the results of Kazatchkine et al,? though not mentioned by them, is that factor VIII-rich preparations could be used in the management of the bleeding diathesis of patients with CRF undergoing haemodialysis. On the basis of our data, we would caution against any hasty generalising of such a therapeutic approach. Indeed, the cause of the bleeding tendency found in many patients with CRF is still to be established.

Judith Baggott, Anna Mancini, Paola Seminari, and Vincenzo De Ceglie helped in preparing the manuscript. This investigation was supported in part by the Associazione Bergamasca per lo Studio delle Malattie Renali.

Requests for reprints should be addressed to: Dr Giuseppe Remuzzi, Divisione di Nefrologia e Dialisi, Ospedali Riuniti di Bergamo, Bergamo, Italy.

\section{References}

${ }^{1}$ Salzman, E W, and Neri, L L, Thrombosis et Diathesis Haemorrhagica, $1966,15,84$.

2 Larsson, S O, Scandinavian fournal of Haematology, 1971, suppl No 15, p 1.

3 Rabiner, S F, Medical Clinics of North America, 1972, 56, 221.

4 Eknoyan, G, et al, New England fournal of Medicine, 1969, 280, 677.

${ }^{5}$ Horowitz, H I, Archives of Internal Medicine, 1970, 126, 823.

${ }^{6}$ Praga, C, et al, in Actualités Néphrologiques de l'Hôpital Necker, p 137. Paris, Flammarion, 1968.

${ }^{7}$ Kazatchkine, M, et al, British Medical fournal, 1976, 2, 612.

${ }^{8}$ Remuzzi, G, et al. Submitted for publication.

${ }^{9}$ Castaldi, P A, Rozenberg, N C, and Stewart, J H, Lancet, 1966, 2, 66.

${ }^{10}$ Bouma, B N, et al, Nature New Biology, 1972, 236, 104

11 Weiss, H J, New England fournal of Medicine, 1974, 290, 464.

12 Praga, C, Cortellaro, M, and Pogliani, E, in Platelet Function and Thrombosis. A review of Methods, ed P M Mannucci and S Gorini, p 149. New York, Plenum Press, 1972.

${ }^{13}$ Hellem, A J, Scandinavian fournal of Haematology, 1970, 7, 374.

14 de Gaetano, G, et al, Thrombosis Research, 1976, 8, 361.

15 Laurell, C B, Annals of Biochemistry and Experimental Medicine, 1966, 15, 45.

16 Italian Working Group, British fournal of Haematology, 1977, 35, 101

17 Weiss, H J, et al, fournal of Clinical Investigation, 1973, 52, 2708.

${ }^{18}$ Macfarlane, D E, et al, Thrombosis et Diathesis Haemorrhagica, 1975, 34, 306.

19 Macfarlane, D E, Thrombosis and Haemostasis, 1976, 36, 282.

${ }^{20}$ Olson, J D, et al, American fournal of Clinical Pathology, 1975, 63, 210.

${ }^{21}$ Holmberg, L, and Nilsson, I M, Scandinavian fournal of Haematology, $1974,12,221$.

${ }^{22}$ Ratnoff, O D, and Bennett, B, New England Fournal of Medicine, 1973, 289, 1182.

${ }^{23}$ Mannucci, P M, et al, fournal of Laboratory and Clinical Medicine, 1976, $\mathbf{8 8}, 662$.

(Accepted 30 May 1977)

\title{
Spina bifida and anencephaly: Are miscarriages a possible cause?
}

\author{
K M LAURENCE, C J ROBERTS
}

British Medical fournal, 1977, 2, 361-362

\section{Summary}

The marriage-to-conception interval in 151 pregnancies producing infants with anencephaly or spina bifida was not significantly different from that in 218 pregnancies resulting in normal infants. Significantly more miscarriages occurred before than after the birth of 285 infants with anencephaly or spina bifida, but in 133 controls no before-after difference was observed.

These observations seem to favour the idea that miscarriages are a manifestation rather than a cause of anencephaly and spina bifida.

\section{Introduction}

The hypothesis that anencephaly and spina bifida (ASB) might be due to an interaction between twin fetuses or between a fetus and residual trophoblastic material from a previous normal

Welsh National School of Medicine, Heath Park, Cardiff

K M LAURENCE, DSC, MRCP, professor of paediatric research, department of child health

C J ROBERTS, MD, PHD, senior lecturer, department of community medicine pregnancy was put forward by Clarke et al ${ }^{1}$ among others. They suggested that information from miscarriages might support such a hypothesis, and, combining the information from several investigations, including a large family study from South Wales," they found more miscarriages before than after an ASB pregnancy, but the interval between miscarriage and the next pregnancy was no higher in cases of ASB than in other pregnancies. They thought that the former finding supported their hypothesis while the latter did not.

We examined the information on miscarriages in a large number of women not included in the analyses of Clarke et al in the hope that it might throw further light on the subject.

\section{Patients and methods}

The obstetric histories of two series of women were reviewed. The first series consisted of 1087 women who attended the genetic advisory service in Cardiff between 1967 and 1976 for various problems. An accurate obstetric history was taken, which included details of all miscarriages. In respect of pregnancies resulting in either stillbirths or live births, the length of gestation or the date of the last menstrual period, the date of delivery, and any malformations present were recorded.

The second series comprised 867 women living in Glamorgan and Gwent who had a pregnancy resulting in an offspring with a major ASB malformation from January 1962 to December 1972 and who were subsequently visited and interviewed in their homes in 1968-74 as part of an investigation into possible causal factors. They included the mothers of all infants with ASB born within an area of about 20 